\title{
VPLIV PADAVINSKIH IN TEMPERATURNIH RAZMER NA ŠIRINO LETNIC ČRNIH BOROV (PINUS NIGRA) V SUBMEDITERANSKI SLOVENIJI
}

\section{Darko Ogrin*}

\section{IZVLEČEK}

UDK 551.58:630*5 (497.12-15)

$\mathrm{V}$ prispevku je opisan odnos med klimo in šrino letnic na primeru $\check{c}_{\mathrm{r} n i h}$ borov iz submediteranske Slovenije. S pomox̌jo dendroklimatološke metode je ugotovljeno, da imajo najvex $x_{j i}$ vpliv na debelinski prirast padavine v vegetacijski sezoni.

ABSTRACT

UDC 551.58:630*5 (497.12-15)

THE INFLUENCE OF PRECIPITATIONS AND TEMPERATURE CONDITIONS ON BLACK PINE (PINUS NIGRA) TREE-RING'S WIDTH IN THESUBMEDITERRANEAN PART OF SLOVENIA

The relationship between climate and tree-ring's width on the example of black pines from submediterranean Slovenia is described. By using the dendroclimatological method it is shown that the biggest influence on radial growth have the precipitations in vegetation period.

\section{UVOD}

$\mathrm{Z}$ odkrivanjem zakonitosti prirašanja dreves se ukvarja gozdarsko prirastoslovje (M.Kotar,1986; V.Stamenkovic 1974; P.R.Morcy,1973), s studijem odnosov med klimo in Sirino drevesnih letnic $\mathrm{v}$ sedanjosti in preteklosti, pa dendroklimatologija (H.C.Fritts,1976; P.de Martin,1970).

Rast drevja je zapleten proces, ki ga uravnavajo క̌tevilni dejavniki. V genetiðni konstituciji dreves je fiksirano določno obnaßanje same rasti, vendar pa to obnasanje modificira vpliv dejavnikov iz okolja.Naše domace dievesne vrste rastejo $s$ podaljševanjem poganjkov (višinska rast) ter $z$ debelitvijo debla (kambijalni ali debelinski prirastek). Nasplošno je rast $\mathrm{v}$ višino bolj odvisna od asimilacijskih pogojev prejšnjega leta, medtem ko je debelinski prirastek bolj odvisen od klimatskih in prehrambenih pogojev tekocega leta (M.Kotar,1986 str.44,70).

Klimatski signal, ki je zapisan v Sirini drevesnih letnic, pa ni povsod jasno izražen. Izrazitejši je v območjih, kjer je klima eden od odločinih faktorjev, ki pogojuje prirast. V literaturi so opisani primeri dendroklimatoloßkih razishav v semiaridnih in. aridnih podroxjih (L.J.Graumlich,1987; H.C.Fritts, 1966), ob zgornji gozdni (drevesni) meji (K.J. Hansen-Bristow in ostali,1988; O.IFeikkinen,1985) in ob polarni gozdni meji (H.C. Garfinken in ostali,1980; I.Hustic,1978):

\footnotetext{
* Prof.geograf., stažist raziskovalec, Oddelek za geografijo, Filozofska fakuiteta, 61000 Ljubljana, AškerCeva 12, YU.
} 


\section{LOKACIJE VZORČENJA}

V Sloveniji కe nimamo studij o odnosih med klimo in debelinskim prirastkom po posameznih pokrajinskih tipih. Glede na dendroklimatološke raziskave, ki so bile narejene $\mathbf{v}$ aridnih in semiaridnih podrocjih drugod po svetu, se nam je zdel del Slovenije, ki je pod vplivom submediteranskega podnebja, primeren za raziskavo odnosov predvsem med padavinami $v$ vegetacijski sezoni in debelinskim prirastkom. PriCakovali smo, da so padavine $\mathrm{v}$ vegetacijski sezoni - zaradi submediteranskega padavinskega režima, $\mathrm{z}$ bolj ali manj izrazito suŠno dobo $\mathrm{v}$ poletnih mesecih (slika 1), ki jo potencira š pretežno kraški znađaj površja - dejavnik, ki znađilno vpliva na rast in s tem na Sirino drevesnih letnic. V letih $\mathrm{z}$ višjo vsoto padavin $\mathrm{v}$ poletnih mesecih naj bi bil prirastek večji, in obratno, v izrazito suŠnih letih naj bi bile drevesne letnice cžje. Opisana zveza pa ni funkcionalna ampak statistiðna.

$\mathrm{Za}$ dendroklimatološko analizo so primerne drevesne vrste, ki imajo dobro vidne Ietnice in so prostorsko dovolj razSir jene. Iz slovenskega submediteranskega prostora sta primerna predvsem hrast in bor. Zaradi jemanja vzorcev $\mathrm{z}$ gozdarskim prirastnim svedrom smo izbrali Crni bor (Pinus nigra).

Izbrane so bile tri lokacije vzorcenja (tabela 1): dve s Podgorskega krasa (Petrinje in Socerb) in ena iz flišnega dela Slovenske Istre (Bržanija). $Z$ vsake od lokacij smo vzeli po 10 izvrtkov. Izvrtki so bili narejeni na drevesih priblixno iste starosti v prsni višini. Pazili smo, da izbrana dïevesa na zunaj niso kazala motenj v priraščnju (vetrolomi,požari,napadi insektov,posegi človeka) in da so rasła tolj na samem (izlo ̌en vpliv konkurence med drevesi na prirast).

\section{METODOLOGIJA DELA}

Zato, da bi odkrili zvezo med klimo in Sirino drevesnih letnic, smo uporabili standarủne metcdološke postopke, opisane $\mathrm{v}$ dendrokiimatološki literaturi (H.C.Fritts,1976; M.K.Hughes in ostali,1982).

Vzorce smo najprej primerno obdelali, da smo pove飞ali vidijivost letnic. Širino letnic smo meriii na "Digitalpositiometru" na $1 / 100 \mathrm{~mm}$ natan ${ }^{\text {no. Za }} \mathrm{Z}$ vsak vzorcc smo sestavili kronologijo letnic - vsaki izmerjeni Sirini letnic smo pripisaii leto v kateri je nastala. Sledilo je t.i. "križno datiranje", to je grafixne predstavitve kronologij vzorcev iz ene lokacije smo primerjali med scboj, ugotavljali variabilnost in sinhronost v prirašcanju, ter od̉stranjevali morebitne napake pri datiranju. $\mathrm{V}$ nadaljevanju so bile izdelane povpreðne kronologije za posamezne lokacije. Grafixna primerjava vzorcev znotraj lokacij, kakor tudi med lokacijami (slika 2) je pokazala, da obstaja med njimi velika sinhronost $v$ prirašanju. Na podlagi te ugotovitve je bila izdelana skupna kronologija za vse tri lokacije. Kronologija zajema obciobje 34 let, co leta 1955 do 
leta 1988. Dolžino je narekovala najkrajš, zanesljivo datirana kronologija.

Širina drevesnih letnic se s starostjo dreves spreminja. Do kulminacije debelinskega prirastka, ki ga razlix̌ne vrste borov dosežejo med 8.in 15. letom (V.Stamenković,1974) naraš̌a, nato postopoma upada, dokler prirast ne prencha. Da bi odpravili vpliv starosti na Sirino letnic, smo izvedli t.i. "izravnavo". S pomocjo 7-letnih drsecih sredin smo izracunali krivuljo biološkega poteka rasti. Od te krivulje pa smo do dejanskih prirastkov v posameznih letih, ki nihajo okoli nje v odvisnosti od pogojev $\mathbf{v}$ neposrednem okolju, izracunali indekse. Indekse smo predstavili kot casovno serijo. Trend biološkega poteka rasti za naše vzorce je pokazal, da so vsa drevesa že dosegla kulminacijo debelinskega prirastka in da v obdobju, ki ga zajema kronologija, kažejo postopen upad prirastka.

\section{KLIMATSKI PODATKI}

Nadaljnji postopek odkrivanja klimatskega signala zapisanega $\mathbf{v}$ sirini drevesnih letnic terja izbor meteorološke postaje, $\mathrm{ki}$ im dolgoletne kvalitetne meritve in $\mathrm{ki}$ odraža klimatske razmere območja za katerega smo izdelali kronologijo.

V bližini izbranih lokacij sta dve meteoroloski postaji: Kubed in Kozina. Kvalitetnejse in dolgoletne meritve ima Kubed (n.v.262 m). Zato smo za primer javo s podatki o Šrini letnic izbrali podalike te postaje.

Dva klimatska elementa, ki najboij vplivata na rast, sta temperature in padavine. Rast $\mathrm{v}$ nekem letu pa ni odvisna samo od temperaturnih in padavinskih razmer tekoCega leta, ampak tudi od razmer $v$ prejšnjem letu. Za rast, predvsem $v$ začetku vegetacijske sezone, je pomembna kolixina rezervnih snovi,ki jo je drevo uspelo uskladi$\zeta x_{i t i}$ v prejšnji vegetacijski sezoni. Pomembne so tudi klimatske razmere v jesenskih mesecih, ko se drevje pripravlja na zimsko mirovanje in sam potek dobe mirovanja. Zaradi naštetih vzrokov so bile $\mathrm{v}$ primerjavo s podatki o క̌irini drevesnih letnic v določnem letu vključene mesexne vrednosti za padavine in temperature od maja $\mathrm{v}$ pretekli vegetacijski sezoni, pa do oktobra tckoðega leta, ko se rast zaključi. Skupno torej 18 mesecev.

\section{REZULTATI}

Posamezne 34-letne nize podatkov mesexnih padavinskih in temperaturnih vrednosti smo $s$ korelacijsko analizo primerjali $z$ enako dolgim nizom podatkov o sirini letnic. Rczultati z vrednosimi korelacijskega koeficienta ( $(\mathrm{r})$, t-testom (t) in s preizkusom statistiene pomembnosti korelacije (p), so zbrani v tabeli 2 . 
V skladu z nasimi prixakovanji je korelacijska analiza pokazala, da imajo najve $\chi_{j i}$ vpliv na debelinski prirast padavinske razmere od maja do septembra tekocega leta $(r=0.1547$ do 0.4448$)$. Še trdnejšo zvezo dobimo, ce namesto mese飞nih vrednosti primerjamo s širino letnic kolið̌no padavin v celotni vegetacijski sezoni $(r=0.6398$, slika 4). Čeprav niso vsi korelacijski koeficienti statistið̌no pomembni, nakazujejo rezultati zvezo tudi med prirastkom in padavinami od januarja do aprila tekocega leta. Vißja kolixina padavin v teh mesecih deluje na na prirast zaviralno.

Manj trdne zveze je korelacijska analiza pokazala pri primerjavi prirastka s temperaturnimi razmerami. Razpoznaven je negativen vpliv viših temperatur $\mathrm{v}$ vegetacijski sezoni, predvsem maja in avgusta $(r=-0.3598$, oz. -0.3718$)$, oziroma pozitiven vpliv spomladanskih temperatur, predvsem marca $(r=0.4078)$.

Blizu statistixne pomembnosti so korelacijski koeficienti primerjave med Sirino letnic in temperaturnimi razmerami $v$ jesenskih mesecih prejకnjega leta. $V$ nasprotju $\mathrm{z}$ drevesi, ki rastejo $\mathrm{v}$ celinskem podnebju in za katera so nekatere studije ugotovile (K.J.Hansen-Bristow in ostali,1988), da visje jesenske temperature pozitivno vplivajo na prirast, ki se oblikuje naslednje lcto, naši rezultati nasprotno kažejo, na negativen vpliv visjih jesenskih temperatur na prirast ernega bora v słovenskih pokrajinah, ki so pod vplivom submediteranskcga podnebja.

Za kompleksnejşi prikaz, oziroma odkrivanje vpliva temperaturnih in padavinskih razmer na rast, se v dendroklimatologiji uporablja t.i."odzivna funkcija" (response function). Bistvo takšnega prikaza je, da nam položaj narisane toðke prcđistavlja stopnjo korelacije med prirastkom in obema variablama za določen mesec. Nucii pa nam tudi vpogled $v$ to, kako katera od možnih kombinacij temperaturnih in padavinskih razmer po posameznih mesecih ali letnih Casih vpliva na rast (M.K.Hughes in drugi, 1982).

$\mathrm{V}$ nasem primeru (slika 4 ) je bila os $\mathrm{x}$ uporabljena za nanos korelacijskih koeficientov za padavine, os y pa za temperature po posameznih mesecih, od maja v prejšnji vegetacijski sezoni (na sliki 4 P.MAJ itd), pa do oktobra v tekoði sezoni. Kot statistixno pomembni so bili upoštevani korelacijski koeficienti $z$ vrednostmi visjimi od +0.20 .

Po tej mctodi, so v submediteranski Sloveniji za rast borov ugodnejకa leta, ki imajo vlažnejక̌ in hladnejšo vegetacijsko sezono (obdobje od maja do vkljucno septembra). Večji vpliv na prirast imajo vlažnostne razmere. Manj izrazit je pomen tople ter suhe pozne zime in zgodnje pomladi (meseci januar, februar, in marec). Še manjsi je pomen mokre in hladnejše jeseni prejšnjega leta (meseci scptember, oktober, deccmber). 
leta 1988. Dolžino je narekovala najkrajsa, zanesljivo datirana kronologija.

Širina drevesnih letnic se s starostjo dreves spreminja. Do kulminacije debelinskega prirastka, ki ga razlǐ̌ne vrste borov dosežejo med 8.in 15. letom (V.Stamenković,1974) naraša, nato postopoma upada, dokler prirast ne prencha. Da bi odpravili vpliv starosti na Širino letnic, smo izvedli t.i. "izravnavo". S pomočjo 7-letnih drsečih sredin smo izraCunali krivuljo bioloskega poteka rasti. Od te krivulje pa smo do dejanskih prirastkov v posameznih letih, ki nihajo okoli nje v odvisnosti od pogojev $\mathrm{v}$ ncposrednem okolju, izracunali indekse. Indekse smo predstavili kot casovno serijo. Trend biološkega poteka rasti za naše vzorce je pokazal, da so vsa drevesa že dosegla kulminacijo debelinskega prirastka in da v obdobju, ki ga zajema kronologija, kažejo postopen upad prirastka.

\section{KLIMATSKI PODATKI}

Nadaljnji postopek odkrivanja klimatskega signala zapisanega $\mathrm{v}$ Sirini drevesnih letnic terja izbor meteorološke postaje, ki im dolgoletne kvalitetne meritve in ki odraža klimatske razmere obmoðja za katcrega smo izdelali kronologijo.

V bližini izbranih lokacij sta dve meteorološki postaji: Kubed in Kozina. Kvalitetnejక̌e in dolgoletne meritve ima Kubed (n.v. $262 \mathrm{~m}$ ). Zato smo za primer javo s podatki o Sirini letnic izbrali podatike te postaje.

Dva klimatska elementa, ki najbolj vplivata na rast, sta temperature in padavine. Rast $\mathrm{v}$ nekem letu pa ni odvisna samo od temperaturnih in padavinskih razmer tekoCega leta, ampak tudi od razmer $v$ prejšnjem letu. Za rast, predvsem $v$ začetku vegetacijske sezone, je pomembna kolicina rezervnih snovi,ki jo je drevo uspelo uskladi$\zeta x_{i t i}$ v prejšnji vegetacijski sezoni. Pomembne so tudi klimatske razmere v jesenskih mesecih, ko se drevje pripravlja na zimsko mirovanje in sam potek dobe mirovanja. Zaradi naštetih vzrokov so bile $\mathrm{v}$ primerjavo $\mathrm{s}$ podatki o క̇irini drevesnih letnic $\mathrm{v}$ doloxenem letu vključene mesexne vrednosti za padavine in temperature od maja v pretekli vegetacijski sezoni, pa do oktobra tckoðega leta, ko se rast zakljuci. Skupno torej 18 mesecev.

\section{REZULTATI}

Posamezne 34-letne nize podatkov meseenih padavinskih in temperaturnih vrednosti smo $s$ korelacijsko analizo primerjali $z$ cnako dolgim nizom podatkov o širini letnic. Rezultati z vrednostmi korelacijskega koeficienta $(r)$, t-testom ( $t$ ) in s preizkusom statistiene pomembnosti korelacije (p), so zbrani v tabeli 2 . 
V skladu z nasimi priðakovanji je korelacijska analiza pokazala, da imajo najve $x_{j i}$ vpliv na debelinski prirast padavinske razmere od maja do septembra tekoðega leta ( $r=0.1547$ do 0.4448$)$. Še trdnejšo zvezo dobimo, re namesto mesernih vrednosti primerjamo $s$ Sirino letnic koli $x_{i n o}$ padavin $v$ celotni vegetacijski sezoni $(r=0.6398$, slika 4). Čeprav niso vsi korelacijski koeficienti statistiðno pomembni, nakazujejo rezultati zvezo tudi med prirastkom in padavinami od januarja do aprila tekocega Ieta. Vißja kolixina padavin v teh mesecih deluje na na prirast zaviralno.

Manj trdne zveze je korelacijska analiza pokazala pri primerjavi prirastka s temperaturnimi razmerami. Razpoznaven je negativen vpliv visjih temperatur v vegetacijski sezoni, predvsem maja in avgusta $(r=-0.3598, o z .-0.3718)$, oziroma pozitiven vpliv spomladanskih temperatur, predvsem marca $(r=0.4078)$.

Blizu statistiěne pomembnosti so korelacijski koeficienti primerjave med Sirino letnic in temperaturnimi razmerami $v$ jesenskih mesecih prejšnjega leta. $V$ nasprotju $\mathrm{z}$ drevesi, ki rastejo $\mathrm{v}$ celinskem podnebju in za katera so nekatere studije ugotovile (K.J.Hansen-Bristow in ostali,1988), da visje jesenske temperature pozitivno vplivajo na prirast, ki se oblikuje naslednje lcto, naši rezultati nasprotno kažejo, na negativen vpliv višjih jesenskih temperatur na prirast ěrnega bora v słovenskih pokrajinah, ki so pod vplivom submediteranskcga podnebja.

Za kompleksnejsi prikaz, oziroma odkrivanje vpliva temperaturnih in padavinskin razmer na rast, se v dendroklimatologiji uporablja t.i."odzivna funkcija" (response function). Bistvo takšnega prikaza je, da nam položaj narisane tocke prcđstavlja stopnjo korelacije med prirastkom in obema variablama za določen mesec. Nucii pa nam tudi vpogled $\mathrm{v}$ to, kako katera od možnih kombinacij temperaturnih in padavinskih razmer po posameznih mesecih ali letnih casih vpliva na rast (M.K.Hughes in drugi, 1982).

$\mathrm{V}$ nasem primeru (slika 4 ) je bila os $\mathrm{x}$ uporabljena za nanos korelacijskih koeficientov za padavine, os y pa za temperature po posameznih mesecih, od maja v prejకnj: vegetacijski sezoni (na sliki 4 P.MAJ itd), pa do oktobra v tekoxi sezoni. Kot statistixno pomembni so bili upostevani korelacijski koeficienti $z$ vrednostmi visjimi od +0.20 .

Po tej mctodi, so v submediteranski Sloveniji za rast borov ugodnejక̌a leta, ki imajo vlažnejకo in hladnejక̧o vegetacijsko sezono (obdobje od maja do vkljueno septembra). Večji vpliv na prirast imajo vlažnostne razmere. Manj izrazit je pomen tople ter suhe pozne zime in zgodnje pomladi (meseci januar, februar, in marec). Še manjłi je pomen mokre in hladnejక̌ jeseni prejšnjega leta (meseci scptember, oktober, deccmber). 


\section{ZAKLJUČEK}

Dendroklimatologija zasieduje $\mathrm{v}$ glavnem dva cilja. Prvi, ki ga je priðujoła raziskava $v$ dobri meri dosegla, je odkrivanje odnosov med prirastkom dreves ter klimo. Drugi cilj pa je rekonstrukcija kiimatskih razmer $v$ obdobjih, za katera §e nimamo meteoroloskih meritev. Izhodisce za rekonstrukcijo so ugotovljene zveze med prirastkom in klimo $v$ sedanjosti. Bolj kot so te zveze trdnc, zanesljivejša je rekonstrukcija. Iz opisanega primera sledi, da so crni bori v submediteranski Sloveniji najbolj obcutljivi na padavinske razmere $v$ vegetacijski sezoni $(r=0.6398)$. S padavinami $v$ vegetacijski sezoni lahko torej pojasnimo približno $41 \%$ variance prirastka $\left(r^{2}=\right.$ 0.4093). S pomoxjo kronologij letnic ernega bora, ki bi segale stcletja nazaj, bi lahko na podlagi ugotovljene zveze ugotavljali leta, oziroma obdobja, s sušnejłimi, oziroma mokrotnejximi poletji. $V$ tem primeru pa se to ne da, ker je Crni bor pri nas alohtona drevesna vrsta, ki so jo zaceli saditi pred približno sto leti. Ker predvidevamo, da podobno kot Črni bor reagira na klimatske razmere $v$ submediteranski Sloveniji tudi hrast, je ta drevesna vrsta zaradi starosti, ki jih dosega in splošne uporabnosti v preteklosti, bolj primerna za sestavo kronologij in rekonstrukcijo klimatskih razmer s pomoxjo njih.

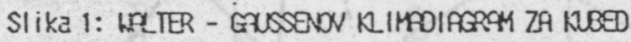

Fig 1: HALIER - GLONON CIIPDIPGRAN FOR KLBED

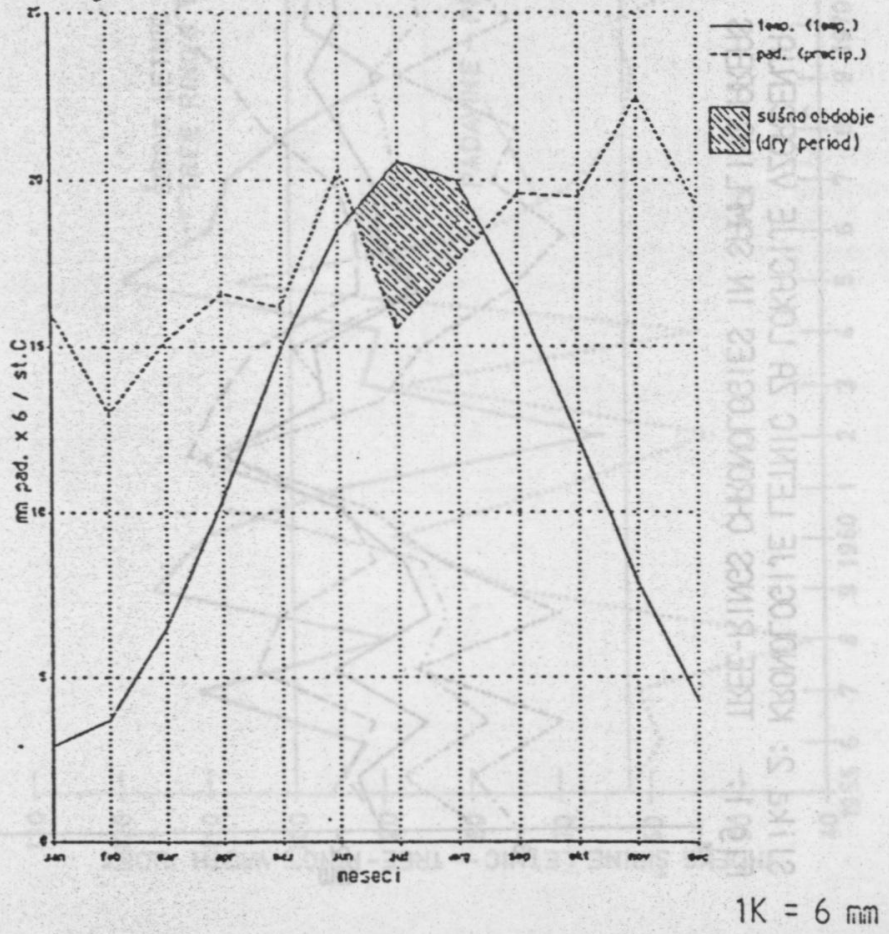




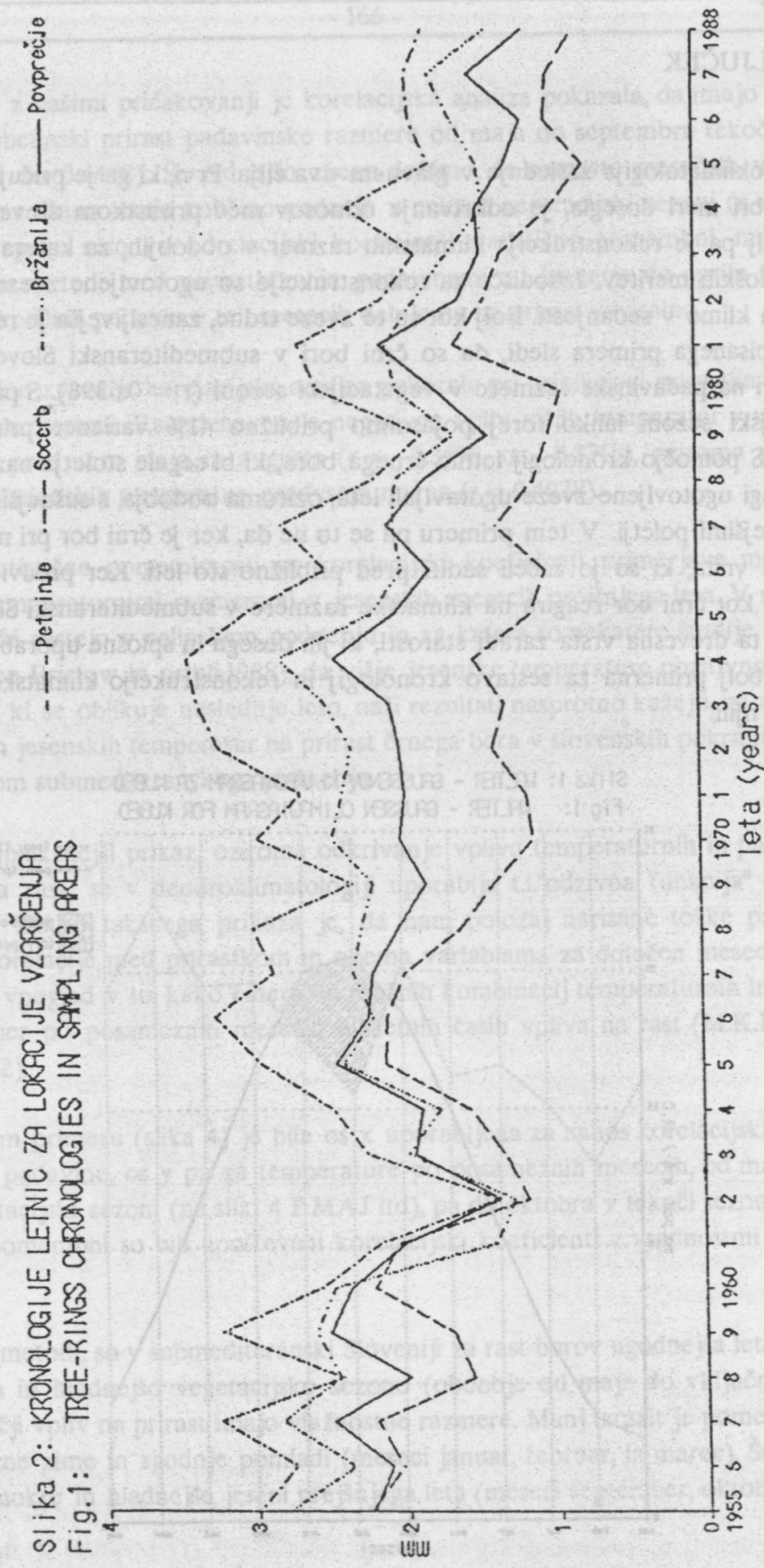




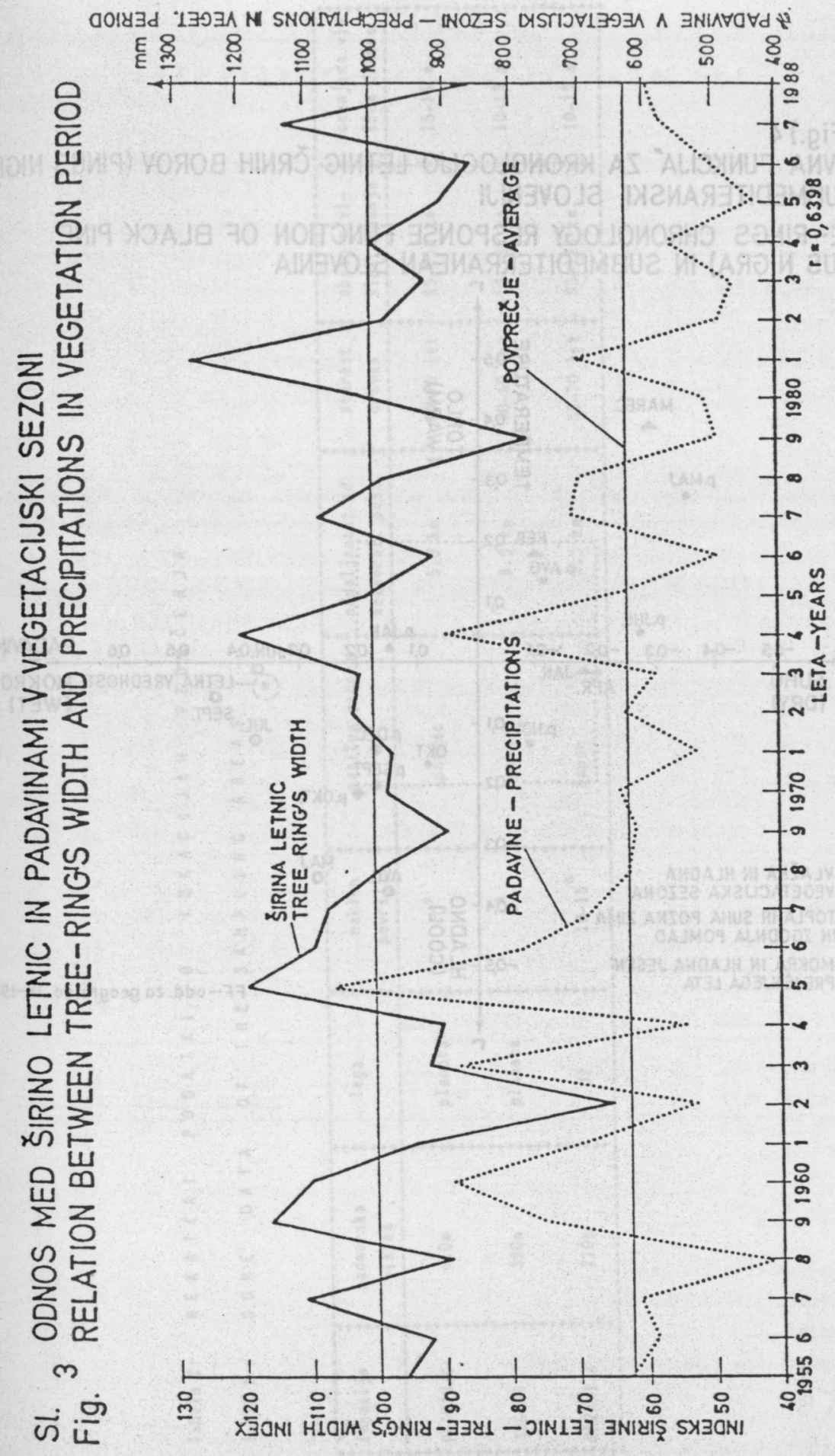


SI.(Fig.) 4

DDZIVNA FUNKCIJA" ZA KRONOLOGIJO LETNIC ČRNIH BOROV (PINUS NIGRA) $\checkmark$ SUBMEDITERANSKI SLOVENIJI

TREE-RINGS CHRONOLOGY RESPONSE FUNCTION OF BLACK PINE (PINUS NIGRA) IN SUBMEDITERRANEAN SLOVENIA

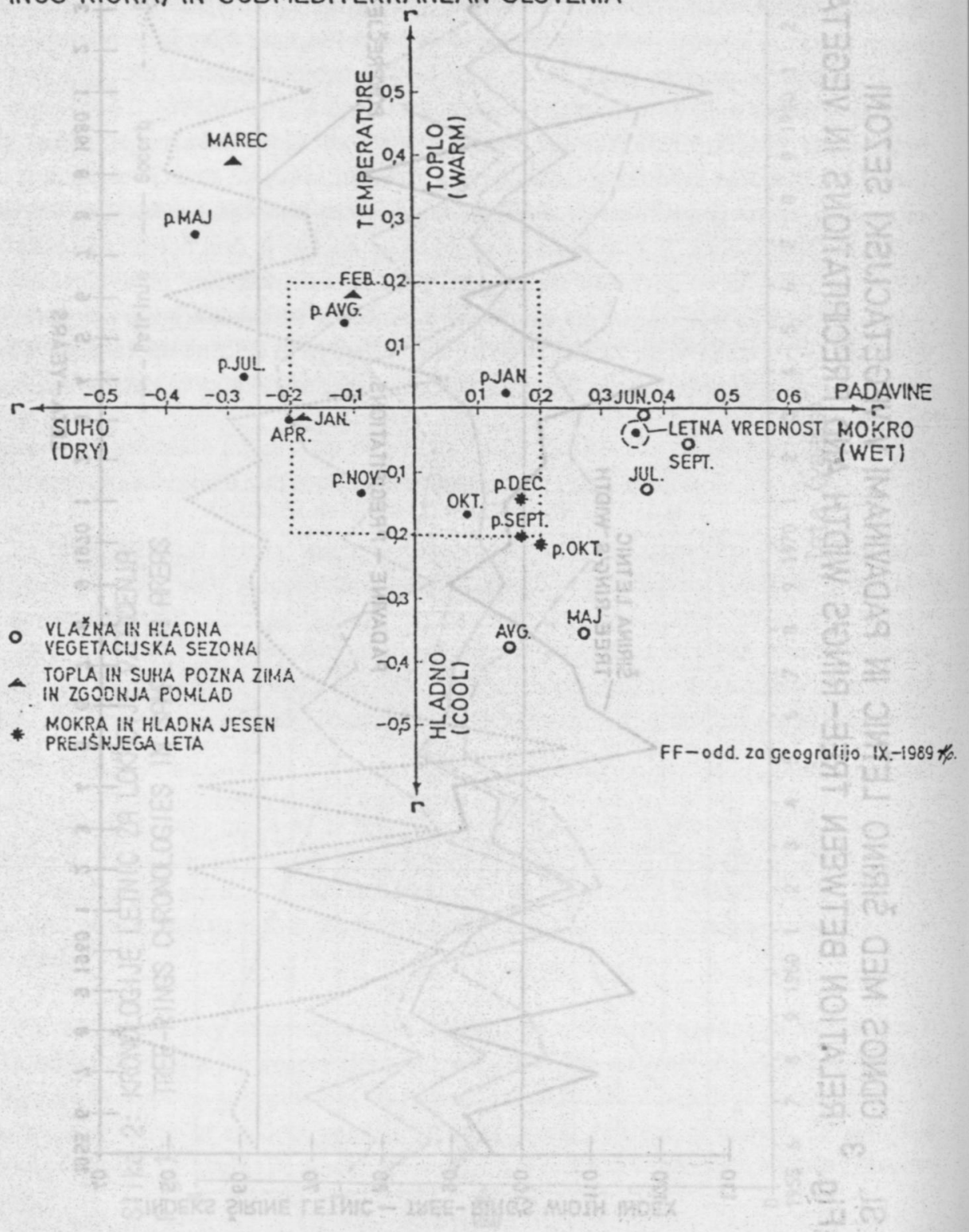




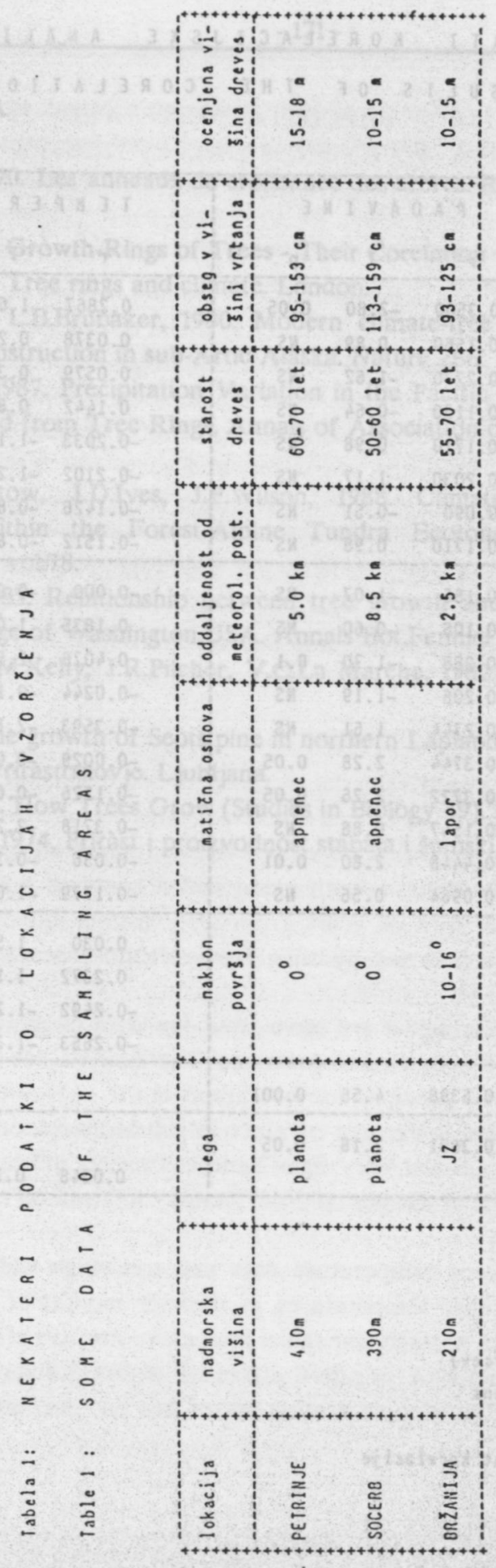


Tabela 2: REZULTATI KORELACIJSKE ANALIZE Table 2: THE RESULTS OF THE CORELATIOH ANALYSIS

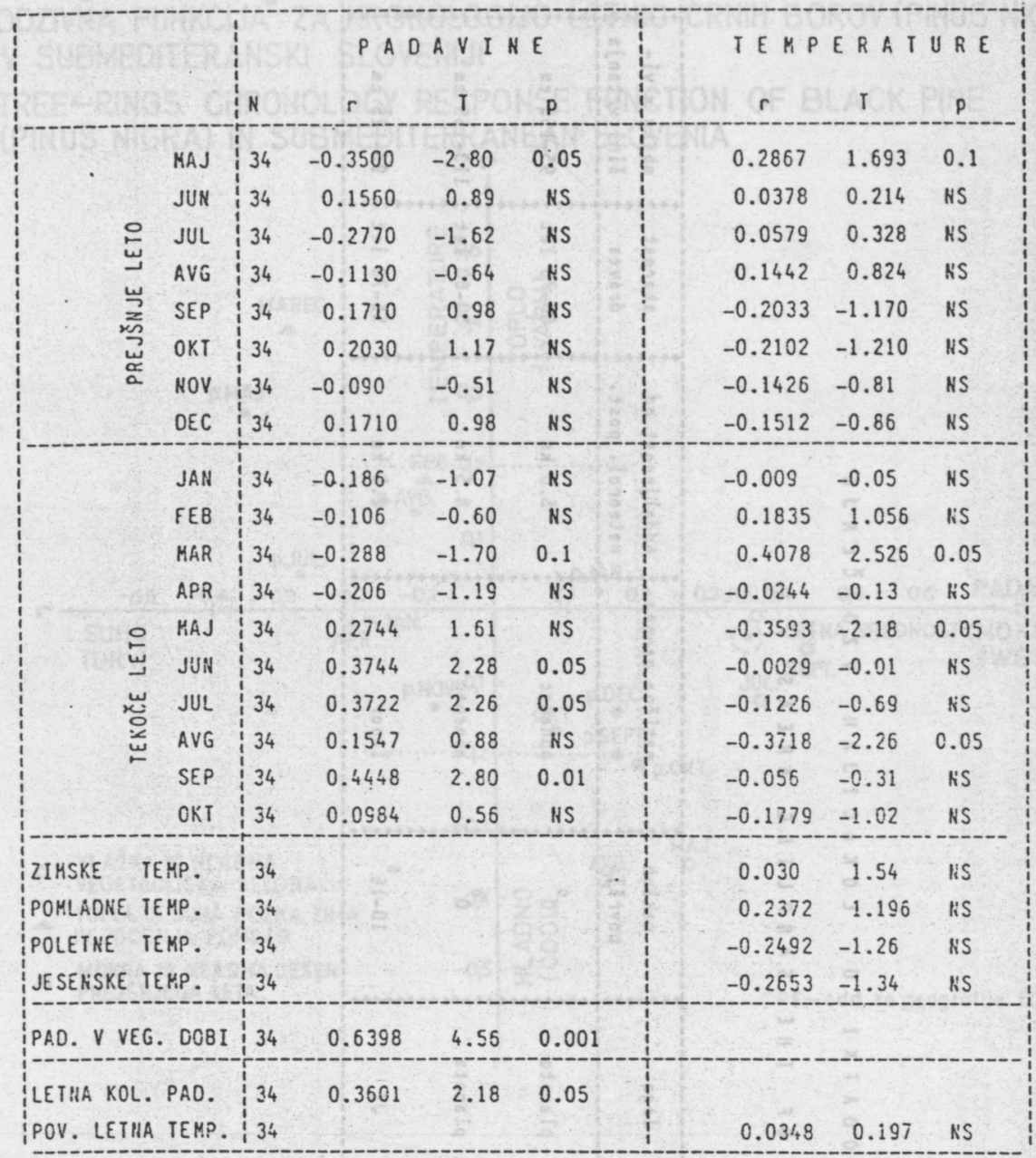

LE GENDA

$H$ - numerus (število vzorcev)

$r$ - korelacijski koeficient

$T$ - t-test

p - statistična ponembnost korelacije 


\section{LITERATURA}

P.de Martin, 1970. Les anneaux de croissance des arbres. Revue geographiqe de l'Est 3-4.

H.C.Fritts, 1966. Growth-Rings of Trees - Their Corelation with Climate. Science 25. H.C.Fritts, 1976. Tree rings and climate. London.

H.C.Garfinken, L.B.Brubaker, 1980. Modern climate-tree growth relationship and climatic reconstruction in sub-Artic Alaska. Nature 286.

L.J.Graumlich, 1987. Precipitation Variation in the Pacific North west (1675-1975) as Reconstructed from Tree Rings. Annals of Association of American Geographers, vol.77.

K.J.Hansen-Bristow, J.D.Ives, J.P.Wilson, 1988. Climatic Variabiliti and Tree Response within the Forest-Alpine Tundra Ecotone. Annals of American Geographers, vol.78.

O.Heikkinen, 1985. Relationship between tree growth and climate in the subalpine Cascade Range of Washington,USA. Annals Bot.Fennici 22, Helsinki.

M.K.Hughes, P.M.Kelly, J.R.Pilcher, V.C.La Marche, 1982. Climate from tree rings. Cambridge.

I.Hustic,1978. The growth of Scots pine in northern Lapland. Ann. Bot. Fennici 15. M.Kotar, 1986. Prirastoslovje. Ljubljana.

P.R.Morey, 1973. How Trees Grow (Studies in Biology 49). London.

V.Stamenkovic, 1974, Prirast i proizvodnost stabala i Sumskih sastojina. Beograd. 


\section{THE INFLUENCE OF PRECIPITATIONS AND TEMPERATURE CONDITIONS ON BLACK PINE (PINUS NIGRA) TREE-RING'S WIDTH IN THE SUBMEDITERRANEAN PART OF SLOVENIA}

One of the features of the submediterranean climate in Slovenia is that a more or less dry period occurs in summer months (fig. 1) which is increased by predominantly karst surface. Knowing the results of dendroclimatological studies done in the landscapes with similar climatic conditions as in the submediteranean Slovenia, we presume that years with more precipitations during summer months are more favourablc for radial increment (tree-rings are wider) and years with less precipitations during the vegetation period less favourable (tree-rings are narrower).

We have chosen to take samples of black pine (Pinus nigra) because it is wide spread and it has well seenable tree-rings. With an insrement borer we took 30 samples, 10 in each location: Petrinje and Socerb on Podgorski kras and Bržanija in flysch slovene Istra (table 1). The width of tree-rings has been measured to $1 / 100 \mathrm{~mm}$ exactly.

To evaluate the so obtained material we used standard dendroclimatological proccdures. Graphical comparation of individual tree-rings chronologies has show a high degree of sinchronity in increment regardless the location. Average chronologies for each of the three locations have been made and a common one for all of them (fig.2). Chronoiogies deal with 34 years, from 1955 to 1988. Biological influence on radial increment has bcen removed by using 7 -ycars flexible means.

To identify the climatic signal we have used the data of meteorological station Kubed $(262 \mathrm{~m})$, situated near chosen locations. The anaiysis has show - results are presented in table 2 - that precipitation conditions in the vegetation period have the biggest influence on radial increment of pines in submediterranean Slovenia (fig.3). Although the connection is not very significant, the results indicate also a negative influence of precipitations in the period from January to April on radial increment.

The comparison between temperature data and tree-ring's width has shown less reliable connections. Higher teniperatures in summer months of vegetation period have been detected as an obstacle for radial increment. Positive cffect was shown by higher spring temperatures. A negative effect of higher autumn temperatures on radial increment in the following vegetation season has also been indicated. 
To get a more complex presentation of temperature and precipitation conditions on radial increment we have used also the so called "response function"(fig.4). With the use of this method years with more humid and colder vegetation season (May including September) have shown to be more favourable for radial increment. Humidity has appeared to be more important. Less important has appeared to be the influence of hot and dry winter and early spring (January, February, March), even less important has appeared the influence of wet and colder autum in the previous year (September, October, November).

From established connections we derived that black pine in submediterranean Slovenia was adequate for the reconstruction of precipitation conditions in vegetation season in periods, for which we do not have climatic data. In this case that was not rational because first black pine trees were planted about 100 years ago, and for this period we have the measurements of some metcorological stations - so there was no need for such a reconstruction. 